\title{
PRL wt Allele
}

National Cancer Institute

\section{Source}

National Cancer Institute. PRL wt Allele. NCI Thesaurus. Code C52425.

Human PRL wild-type allele is located within 6p22.2-p21.3 and is approximately $10 \mathrm{~kb}$ in length. This allele, which encodes prolactin protein, is involved in the mediation of lactation and embryonic implantation. 